\title{
ENGINEERING PROPERTIES OF SCORIA CONCRETE AS A CONSTRUCTION MATERIAL
}

I. M. AHO AND S. J. UUNGWA

(Received 11 August 2015; Revision Accepted 23 November 2015)

\begin{abstract}
The weight and cost of plain concrete are part of the setbacks in its use for construction purposes especially in low-cost housing delivery. This paper reports the experimental results of samples of concrete produced from a mix combination of cement, fine aggregate (sand) and volcanic scoria as coarse aggregate. The scoria concrete so produced in mix ratio 1:2:4 was tested for compressive strength, flexural strength and water absorption capacity. Empirical values of those factors that affect concrete strength were equally determined, these included specific gravity, bulk density and fineness modulus. The quality of scoria as an aggregate was also assessed by carrying out crushing test, impact value and abrasion tests. The compressive strength and modulus of rupture for $28-$ days samples of scoria concrete was $20.42 \mathrm{~N} / \mathrm{mm}^{2}$ and $6.08 \mathrm{~N} / \mathrm{mm}^{2}$ respectively. This compares well with plain concrete with compressive strength of $22.22 \mathrm{~N} / \mathrm{mm}^{2}$ and flexural strength of $7.14 \mathrm{~N} / \mathrm{mm}^{2}$. The results show that scoria concrete has sufficient strength to be used as a construction material.
\end{abstract}

KEYWORDS: Scoria concrete, Compressive strength, Modulus of rupture, Absorption capacity.

\section{INTRODUCTION}

Shelter is a basic human need, unfortunately decent shelter for the mass of the poor have not materialized over the years. Efforts at mass housing delivery at affordable rates to low income earners have not been successful due to the high cost of construction materials like cement from which concrete is made (Ndububa and Aho, 2004; Okpalla, 1994). Another disadvantage in the use of concrete is its high dead weight, it has an average unit weight of $23 \mathrm{KN} / \mathrm{m}^{3}$.

The use of light weight aggregates to produce light weight concrete has the advantage of reducing the dead weight in building structures (Ndububa et. al. 2009). Other benefits include lower handling and haulage costs. Furthermore, costs are reduced when aggregate materials are readily available, affordable and cheap, hence the present research interest on concrete made from light weight aggregate of volcanic origin.

This paper reports a laboratory programme aimed at determining some engineering properties of concrete produced from cement, sand and scoria as coarse aggregate. The results are compared with plain concrete which serves as control in the experimentation.

Scoria is of volcanic origin usually of basic composition, characterized by marked vesicularity, dark colour, light with a texture that is partly glassy and partly crystalline. The sample for the experimentation was obtained from Wurukum market in Makurdi town. The sample was broken up into aggregate size of $20 \mathrm{~mm}$ to replace coarse aggregate in the concrete mix (see plate 1).

I. M. Aho, Department of Civil Engineering, University of Agriculture, Makurdi, Benue State,

S. J. Uungwa, Department of Civil Engineering, University of Agriculture, Makurdi, Benue State, 


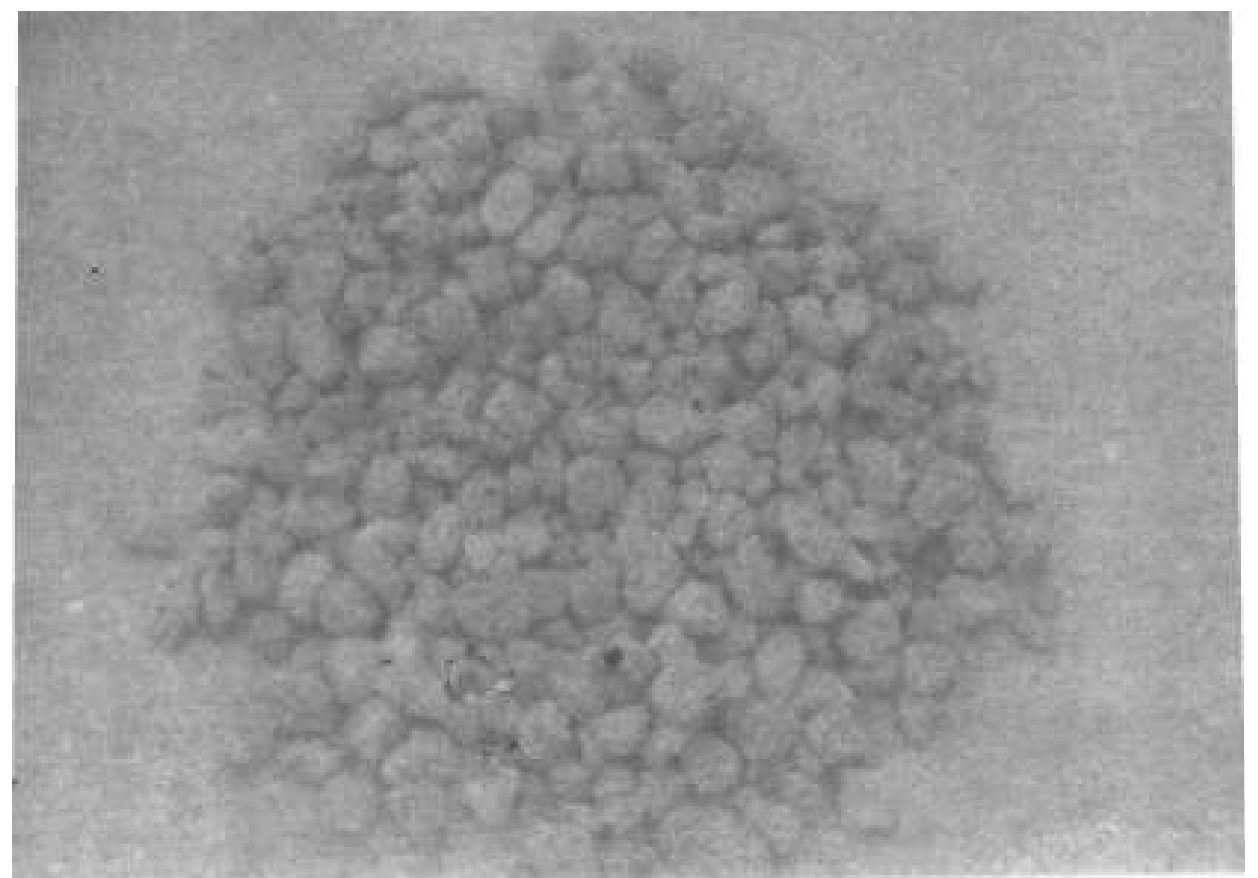

Plate 1: Volcanic scoria aggregates

The laboratory programme was designed to determine compressive strength, flexural strength (i.e. modulus of rupture) and water absorption capacity of the scoria concrete. Other parameters that affect strength like specific gravity, bulk density, impact value, abrasion, and crushing test were determined. The volumetric ratio of one part of cement to two parts of fine aggregates to four parts of scoria (1:2:4) was adopted in line with the American method of mix design. For the designed strength of $20 \mathrm{~N} / \mathrm{mm}^{2}$ with $20 \mathrm{~mm}$ maximum size aggregates and a slump of 80 to $100 \mathrm{~mm}, \mathrm{ACl} 211.1-9$ specified water/cement ratio of 0.70 , water content of $200 \mathrm{~kg} / \mathrm{m}^{3}$ and $2 \%$ entrapped air.

The results show that for 28 - day curing, scoria concrete recorded compressive strength of $20.42 \mathrm{~N} / \mathrm{mm}^{2}$ and $6.08 \mathrm{~N} / \mathrm{mm}^{2}$ flexural strength respectively. There was also a reduction in density in favour of scoria concrete.

\section{Experimental Procedures}

All tests were conducted in accordance with ASTM C208-7 part 18 specification. It specifies the ratio $1: 2: 4$ by weight and a water/cement ratio of 0.70 .

\section{Condition of Materials}

River sand from Benue environs was used. They were washed, oven dried and sieved to conform with Graded Standard Sand, i.e. $1.8 \mathrm{~mm}$ maximum size and $0.150 \mathrm{~mm}$ minimum. Ordinary Portland Cement (OPC) free of clods was used.

Scoria obtained from Wurukum market was broken up into aggregate size of $20 \mathrm{~mm}$ before the sample was washed and oven dried for the experiment.

\section{Mixing of Materials}

Batching was by weight in ratio 1:2:4. The cement was first mixed thoroughly dry with sand before the introduction of scoria. These were thoroughly mixed again before water was added. The mixing continued until a workable mix was achieved in which segregation and balling effects were minimized (BSI, 1975).

\section{Testing of Samples}

Compressive strength and flexural strength tests were conducted in accordance with British Standards. Load was applied gradually by means of laboratory machines. The central point loading was adopted for the flexural test. 
Compression tests were carried out on $150 \times 150$ $x 150 \mathrm{~mm}$ cubes and flexural tests were conducted on $100 \times 100 \times 300 \mathrm{~mm}$ prisms. The water absorption tests were conducted by weighting and re-weighting of specimen after soaking in water over varying periods of time. The ratio between the difference in weight and the original weight is the measure of the water absorption capacity.

\section{RESULTS AND DISCUSSION}

The results of Aggregate Crushing Value (ACV) for both normal (plain) and scoria aggregates were obtained as $5.3 \%$ and $7.8 \%$ respectively as shown in Table 1 . The values fall within the expected range of $5-39$ as specified by BS 812 for unclassified samples. Table 1 also shows the Aggregate Impact Value (AIV) of $33.2 \%$ and $10.4 \%$ for scoria and normal aggregates respectively. The two values are within the expected range of $7-53 \%$ as recommended by BS 812. ASTMC 131 - 64T specifies highest abrasion value of $40 \%$ as against the recorded $36 \%$ for the scoria aggregate in Table 1.

Table 1 further shows the result of specific gravity for normal and scoria aggregate as 2.62 and 2.30 respectively. These values compares well with ASTMC 127 - 93 standards. The lower value for scoria confirms that it can make concrete of low density as against normal weight aggregate (Neville, 1981).

Table 1: Average test values for normal (control) and scoria aggregates

\begin{tabular}{|l|c|c|c|c|c|}
\hline $\begin{array}{l}\text { Type of } \\
\text { Aggregate }\end{array}$ & $\begin{array}{c}\text { Aggregate } \\
\text { crushing } \\
\text { value (\%) }\end{array}$ & $\begin{array}{c}\text { Aggregate } \\
\text { impact value } \\
\text { (\%) }\end{array}$ & $\begin{array}{c}\text { Abrasion } \\
\text { value (\%) }\end{array}$ & $\begin{array}{c}\text { Specific } \\
\text { gravity }\end{array}$ & $\begin{array}{c}\text { Bulk density } \\
\left(\mathbf{K g} / \mathbf{m}^{\mathbf{3}} \mathbf{)}\right.\end{array}$ \\
\hline Normal & 53 & 10.4 & 25 & 2.62 & 1441 \\
\hline Scoria & 7.8 & 33.2 & 36 & 2.30 & 679 \\
\hline
\end{tabular}

The results of compressive strength are presented in Table $2-3$. The 28 - day average strength for scoria concrete is $20.42 \mathrm{~N} / \mathrm{mm}^{2}$ with average density of $1920 \mathrm{Kg} / \mathrm{m}^{3}$. This compares well with values of the control concrete which has the 28-day compressive strength of $23.85 \mathrm{~N} / \mathrm{mm}^{2}$ and a density of $2602 \mathrm{Kg} / \mathrm{m}^{3}$. Furthermore, the 28-day compressive strength of scoria concrete recorded a higher value than the minimum designed strength of $20 \mathrm{~N} / \mathrm{mm}^{2}$.

Table 2: Compressive strength test on plain concrete of mix ratio 1:2:4 with design strength $20 \mathrm{~N} / \mathrm{mm}^{2}$

\begin{tabular}{|c|c|c|c|c|c|c|}
\hline $\begin{array}{l}\text { Cube Ref. } \\
\text { No. }\end{array}$ & $\begin{array}{l}\text { Age of Cube } \\
\text { (days) }\end{array}$ & $\begin{array}{l}\text { Mass of } \\
\text { cube (Kg) }\end{array}$ & $\begin{array}{l}\text { Cube density } \\
\left(\mathrm{Kg} / \mathrm{m}^{3}\right)\end{array}$ & $\begin{array}{l}\text { Crushing } \\
\text { load (KN) }\end{array}$ & $\begin{array}{l}\text { Compressive } \\
\text { strength } \\
\left(\mathrm{N} / \mathrm{mm}^{2}\right)\end{array}$ & $\begin{array}{l}\text { Average } \\
\text { strength } \\
\left(\mathrm{N} / \mathrm{mm}^{2}\right)\end{array}$ \\
\hline $\begin{array}{l}A_{1} \\
A_{2} \\
A_{3}\end{array}$ & 7 & $\begin{array}{l}8.70 \\
8.52 \\
8.81 \\
\end{array}$ & $\begin{array}{l}2578 \\
2524 \\
2610 \\
\end{array}$ & $\begin{array}{l}462 \\
420 \\
440 \\
\end{array}$ & $\begin{array}{l}20.53 \\
18.67 \\
19.56 \\
\end{array}$ & 19.59 \\
\hline $\begin{array}{l}A_{1} \\
A_{2} \\
A_{3}\end{array}$ & 14 & $\begin{array}{l}8.72 \\
8.90 \\
8.81\end{array}$ & $\begin{array}{l}2583 \\
2637 \\
2610 \\
\end{array}$ & $\begin{array}{l}480 \\
490 \\
488 \\
\end{array}$ & $\begin{array}{l}21.33 \\
21.78 \\
21.69 \\
\end{array}$ & 21.60 \\
\hline $\begin{array}{l}A_{1} \\
A_{2} \\
A_{3}\end{array}$ & 28 & $\begin{array}{l}8.72 \\
8.86 \\
8.81\end{array}$ & $\begin{array}{l}2584 \\
2625 \\
2610\end{array}$ & $\begin{array}{l}540 \\
560 \\
510\end{array}$ & $\begin{array}{l}24.00 \\
24.89 \\
22.67\end{array}$ & 23.85 \\
\hline $\begin{array}{l}A_{1} \\
A_{2} \\
A_{3}\end{array}$ & 56 & $\begin{array}{l}8.92 \\
8.84 \\
8.81\end{array}$ & $\begin{array}{l}2643 \\
2619 \\
2610 \\
\end{array}$ & $\begin{array}{l}660 \\
640 \\
620\end{array}$ & $\begin{array}{l}29.33 \\
28.44 \\
27.56 \\
\end{array}$ & 28.44 \\
\hline
\end{tabular}


Table 3: Compressive strength test on scoria concrete of mix ratio $1: 2: 4$ with design strength $20 \mathrm{~N} / \mathrm{mm}^{2}$

\begin{tabular}{|c|c|c|c|c|c|c|}
\hline $\begin{array}{l}\text { Cube Ref. } \\
\text { No. }\end{array}$ & $\begin{array}{l}\text { Age of } \\
\text { Cube } \\
\text { (days) }\end{array}$ & $\begin{array}{l}\text { Mass of } \\
\text { cube }(\mathrm{Kg})\end{array}$ & $\begin{array}{l}\text { Cube } \\
\text { density } \\
\left(\mathrm{Kg} / \mathrm{m}^{3}\right)\end{array}$ & $\begin{array}{l}\text { Crushing } \\
\text { load (KN) }\end{array}$ & $\begin{array}{c}\text { Compressive } \\
\text { strength } \\
\left(\mathrm{N} / \mathrm{mm}^{2}\right)\end{array}$ & $\begin{array}{l}\text { Average } \\
\text { strength } \\
\left(\mathrm{N} / \mathrm{mm}^{2}\right)\end{array}$ \\
\hline $\begin{array}{l}\mathrm{B}_{1} \\
\mathrm{~B}_{2} \\
\mathrm{~B}_{3}\end{array}$ & 7 & $\begin{array}{l}6.60 \\
6.34 \\
4.47\end{array}$ & $\begin{array}{l}1956 \\
1876 \\
1916\end{array}$ & $\begin{array}{l}375 \\
302 \\
324\end{array}$ & $\begin{array}{l}16.67 \\
13.42 \\
14.40\end{array}$ & 14.83 \\
\hline $\begin{array}{l}\mathrm{B}_{1} \\
\mathrm{~B}_{2} \\
\mathrm{~B}_{3}\end{array}$ & 14 & $\begin{array}{l}6.64 \\
6.72 \\
7.04\end{array}$ & $\begin{array}{l}1967 \\
1991 \\
2086\end{array}$ & $\begin{array}{l}392 \\
410 \\
440\end{array}$ & $\begin{array}{l}17.42 \\
18.22 \\
19.56\end{array}$ & 18.40 \\
\hline $\begin{array}{l}\mathrm{B}_{1} \\
\mathrm{~B}_{2} \\
\mathrm{~B}_{3}\end{array}$ & 28 & $\begin{array}{l}6.46 \\
6.50 \\
6.48\end{array}$ & $\begin{array}{l}1914 \\
1920 \\
1920\end{array}$ & $\begin{array}{l}420 \\
484 \\
474\end{array}$ & $\begin{array}{l}18.67 \\
21.51 \\
21.07\end{array}$ & 20.42 \\
\hline $\begin{array}{l}\mathrm{B}_{1} \\
\mathrm{~B}_{2} \\
\mathrm{~B}_{3}\end{array}$ & 56 & $\begin{array}{l}6.21 \\
6.10 \\
6.30\end{array}$ & $\begin{array}{l}1840 \\
1807 \\
1867\end{array}$ & $\begin{array}{l}510 \\
542 \\
550\end{array}$ & $\begin{array}{l}22.67 \\
24.01 \\
24.44\end{array}$ & 23.71 \\
\hline
\end{tabular}

The flexural strength results, measured as modulus of rupture are presented in Tables 4-5. The results for scoria concrete are lower than those of plain concrete due to the weaker interface between the scoria aggregate and the cement and matrix. However, the failure of plain concrete was usually sudden and less stretched due to its brittleness.

Table 4: Flexural strength test on plain concrete of mix ratio 1:2:4

\begin{tabular}{|c|c|c|c|c|}
\hline Cube Ref. No. & $\begin{array}{c}\text { Age of cube } \\
\text { (days) }\end{array}$ & Failure load (KN) & $\begin{array}{c}\text { Modulus of } \\
\text { rupture }\left(\mathrm{N} / \mathrm{mm}^{2}\right)\end{array}$ & $\begin{array}{l}\text { Average strength } \\
\left(\mathrm{N} / \mathrm{mm}^{2}\right) 5.83\end{array}$ \\
\hline $\begin{array}{l}\mathrm{C}_{1} \\
\mathrm{C}_{2} \\
\mathrm{C}_{3}\end{array}$ & 7 & $\begin{array}{l}19.00 \\
19.20 \\
20.10\end{array}$ & $\begin{array}{l}5.70 \\
5.76 \\
6.03\end{array}$ & 5.83 \\
\hline $\begin{array}{l}\mathrm{C}_{1} \\
\mathrm{C}_{2} \\
\mathrm{C}_{3}\end{array}$ & 14 & $\begin{array}{l}24.80 \\
21.00 \\
22.70\end{array}$ & $\begin{array}{l}7.44 \\
6.30 \\
5.87\end{array}$ & 6.87 \\
\hline $\begin{array}{l}\mathrm{C}_{1} \\
\mathrm{C}_{2} \\
\mathrm{C}_{3}\end{array}$ & 28 & $\begin{array}{l}24.00 \\
22.02 \\
25.40 \\
\end{array}$ & $\begin{array}{l}7.20 \\
6.61 \\
7.62 \\
\end{array}$ & 7.14 \\
\hline $\begin{array}{l}\mathrm{C}_{1} \\
\mathrm{C}_{2} \\
\mathrm{C}_{3}\end{array}$ & 56 & $\begin{array}{l}22.20 \\
24.00 \\
24.30 \\
\end{array}$ & $\begin{array}{l}7.26 \\
7.20 \\
7.29 \\
\end{array}$ & 7.25 \\
\hline
\end{tabular}

Table 5: Flexural strength test on scoria concrete of mix ratio 1:2:4

\begin{tabular}{|c|c|c|c|c|}
\hline Cube Ref. No. & $\begin{array}{c}\text { Age of cube } \\
\text { (days) }\end{array}$ & Failure load (KN) & $\begin{array}{c}\text { Modulus of } \\
\text { rupture }\left(\mathrm{N} / \mathrm{mm}^{2}\right)\end{array}$ & $\begin{array}{l}\text { Average strength } \\
\left(\mathrm{N} / \mathrm{mm}^{2}\right) 5.83\end{array}$ \\
\hline $\begin{array}{l}D_{1} \\
D_{2} \\
D_{3}\end{array}$ & 7 & $\begin{array}{l}18.80 \\
18.00 \\
17.96 \\
\end{array}$ & $\begin{array}{l}5.64 \\
5.40 \\
5.37 \\
\end{array}$ & 5.47 \\
\hline $\begin{array}{l}D_{1} \\
D_{2} \\
D_{3}\end{array}$ & 14 & $\begin{array}{l}18.02 \\
20.12 \\
19.20\end{array}$ & $\begin{array}{l}5.41 \\
6.04 \\
5.76\end{array}$ & 5.73 \\
\hline $\begin{array}{l}D_{1} \\
D_{2} \\
D_{3}\end{array}$ & 28 & $\begin{array}{l}21.20 \\
20.10 \\
19.50\end{array}$ & $\begin{array}{l}6.36 \\
6.03 \\
5.58\end{array}$ & 6.08 \\
\hline $\begin{array}{l}D_{1} \\
D_{2} \\
D_{3} \\
\end{array}$ & 56 & $\begin{array}{l}22.00 \\
19.60 \\
20.80 \\
\end{array}$ & $\begin{array}{l}6.60 \\
5.88 \\
6.24 \\
\end{array}$ & 6.24 \\
\hline
\end{tabular}


The results of water absorption capacity of 28day samples are given in Tables 6-7. The absorption capacity was $11.7 \%$ after 14 days of soaking. This compares favourably with the limiting value specified for building boards which is $7 \%$.

Table 6: Water absorption test on 56-day scoria concrete

\begin{tabular}{|l|c|c|c|c|c|}
\hline \multirow{2}{*}{ Cube Ref. No. } & Initial mass $\mathbf{( K g )}$ & \multicolumn{4}{|c|}{ Mass of cube soaked in water (days) } \\
\cline { 3 - 6 } & & $\mathbf{7}$ & $\mathbf{1 4}$ & $\mathbf{2 8}$ & $\mathbf{5 6}$ \\
\hline $\mathrm{E}_{1}$ & 6.10 & 6.60 & 6.64 & 6.64 & 6.66 \\
$\mathrm{E}_{2}$ & 6.00 & 6.34 & 6.72 & 6.73 & 6.74 \\
$\mathrm{E}_{3}$ & 6.16 & 6.47 & 7.04 & 7.04 & 7.04 \\
\hline Average & 6.09 & 6.47 & 6.89 & 6.80 & 6.81 \\
\hline Water absorption capacity (\%) & & 6.3 & 11.7 & 11.8 & 11.9 \\
\hline
\end{tabular}

Table 7: Water absorption test on 56-day plain concrete

\begin{tabular}{|l|c|c|c|c|c|}
\hline \multirow{2}{*}{ Cube Ref. No. } & Initial mass (Kg) & \multicolumn{4}{|c|}{ Mass of cube soaked in water (days) } \\
\cline { 3 - 6 } & & $\mathbf{7}$ & $\mathbf{1 4}$ & $\mathbf{2 8}$ & $\mathbf{5 6}$ \\
\hline $\mathrm{F}_{1}$ & 8.60 & 8.70 & 8.72 & 8.72 & 8.72 \\
$\mathrm{~F}_{2}$ & 8.48 & 8.52 & 8.90 & 8.90 & 8.90 \\
$\mathrm{~F}_{3}$ & 8.38 & 8.81 & 8.81 & 8.81 & 8.81 \\
\hline Average & 8.49 & 8.68 & 8.81 & 8.81 & 8.81 \\
\hline Water absorption capacity (\%) & & 2.3 & 3.83 & 3.83 & 3.83 \\
\hline
\end{tabular}

\section{CONCLUSION}

From the results obtained, scoria concrete is suitable for use as a construction material. But further areas of research are recommended. These include the use of more ratios, altering of workability parameters, introduction of additives and tests on shrinkage properties.

\section{REFERENCES}

American Society for Testing and Materials ASTM 1974. C208-7 part 18, Standard Specifications for Insulating Board Structures and Decorative, Philadelphia, pp. 44-47.

British Standards Institution 1970. BS 1881, Part, Methods of Testing Concrete Strength, BSI London, p. 38.

British Standards Institution 1975. BS 812, Part 2, Testing of Aggregates, London Publishing Copany, Britain.

British Standards Institution 1975. BSI, London.
Ndububa, E. E and Aho, I. M., 2004. Mechanical Strength of Coconut Shell Concrete as a light Weight Structural Material. Published by Enugu State University of Science and Technology. Pp.18-26.

Ndububa, E. E., Aho, M. I and Utsev, J. T., 2009. An Investigation of Bamboo Nut as an Aggregate in Concrete. Nigerian Journal of Engineering Research and Development. 8, (2): Pp. 14-19.

Neville, A. M. 1981. Properties of Concrete. Pitman Publishing, London. Third Edition, pp. 610.

Okpalla, D. C., 1990. Palm Kernel Shells as a Light Weight Aggregate in Concrete Building and Environmental Journal, 1, Pp. $291-296$. 